\title{
Legumes, herbs or grass for lamb performance?
}

\author{
T.J. FRASER ${ }^{1}$ and J.S. ROWARTH ${ }^{1,2}$ \\ ${ }^{1}$ AgResearch, PO Box 60, Lincoln, Canterbury \\ ${ }^{2}$ Plant Science Department, PO Box 84, Lincoln University, Canterbury
}

\begin{abstract}
Lamb performance was evaluated for three consecutive summer-early autumn periods on ryegrass (Lolium perenne), white clover (Trifolium repens), chicory (Cichorium intybus), plantain (Plantago lanceolata) or lotus (Lotus corniculatus). Lamb liveweight gains, fasted liveweights at slaughter and hot carcass weights tended to be highest on legumes and chicory and lowest on plantain and ryegrass. Greasy wool weights were significantly higher on lotus and white clover than on chicory, plantain and ryegrass. Greasy wool weight was significantly related to fasted liveweight $\left(\mathrm{R}^{2}=0.94-0.99\right)$. Protein $(\%)$ in herbage accounted for $83-92 \%$ of the variability in animal performance; food intake accounted for $57-69 \%$ of the variability and was negatively correlated with hemicellulose and cellulose $\left(\mathrm{R}^{2}=97.2\right.$ and $80.9 \%$, respectively). Thus quality of feed was more important than intake alone in determining animal performance.
\end{abstract}

Keywords: carcass weight, Cichorium intybus, greasy wool weight, intake, lamb performance, Lotus corniculatus, Lolium perenne, Plantago lanceolata, Trifolium repens

\section{Introduction}

Meat and wool production are fundamental requirements for animal performance. However, lambs fed traditional ryegrass-white clover (Lolium perenne L.-Trifolium repens $\mathrm{L}$.) pasture do not perform to their full potential because protein supply is sub-optimal (Hughes et al. 1980). With increasing commercial availability of species other than traditional grasses and legumes, research has begun on the effects of these species on animal performance.

Chicory (Cichorium intybus L. cv. Grasslands Puna) was released in New Zealand in 1985 (Rumball 1986) and has been found to give high animal growth rates (Fraser et al. 1988; Clark et al. 1990; Komolong et al. 1992). Growth rates are often higher than that suggested by food intake; the reason is not known, but a protected protein has been hypothesised (Komolong et al. 1992).
Plantain (Plantago lanceolata L. cv. Grasslands Lancelot) was released in New Zealand in 1993. Its potential as a forage herb has been discussed for many years (e.g., Heeger 1949; Ivins 1952; Foster 1988; Wilman \& Riley 1993). It is reported to contain tannin (Launert 1984; Dorfler \& Roselt 1989), to have antibiotic properties (Grieve 1931), to be highly palatable to stock (Milton 1933; Ivins 1952), and to have a high mineral concentration (Thomas et al. 1952).

This trial was established to evaluate the effect of different pasture species on animal performance.

\section{Materials and methods}

Three replicates of five pasture species (high-endophyte ryegrass cv. Grasslands Nui at $20 \mathrm{~kg} / \mathrm{ha}$, white clover cv. Grasslands Huia at $4 \mathrm{~kg} / \mathrm{ha}$, chicory cv. Grasslands Puna at $5 \mathrm{~kg} / \mathrm{ha}$, plantain cv. Grasslands Lancelot at $8 \mathrm{~kg} / \mathrm{ha}$ and Lotus corniculatus L. cv Grasslands Goldie at $4 \mathrm{~kg} / \mathrm{ha}$; all sowing rates were adjusted to $100 \%$ germination) were sown in early October 1992. Plot size was 0.5 ha. Soil type was a Templeton silt loam. Irrigation was applied to keep soil moisture above 50\% field capacity. Nitrogen fertiliser $(50 \mathrm{~kg} / \mathrm{ha} \mathrm{N}$ as urea) was applied in spring and early summer (total $=100 \mathrm{~kg}$ / $\mathrm{ha} / \mathrm{yr})$. Superphosphate $(250 \mathrm{~kg} / \mathrm{ha})$ was applied each autumn. Soil analysis in year two indicated: $\mathrm{pH} 6.0$, Ca 15, K 27, Mg 30, S 13.

In year one of the trial, lotus plots were heavily contaminated with weeds, so measurements did not begin on these plots until year two, when the pasture was $>80 \%$ pure lotus. Herbicides were used as necessary to maintain purity of species and pastures were pre-grazed to give maximum herbage quality of individual species.

The trial was grazed during the summer and early autumn each year from 1992 to 1995 . Twenty Coopworth ram lambs (22-23 kg mean 24-hour fasted liveweight in all three years of the trial) from the same genetic base were weaned, shorn and, after a 10-day adjustment period, were allocated to each treatment at a herbage allowance of approximately $2.0 \mathrm{~kg} \mathrm{DM} / \mathrm{head} /$ day (where $\mathrm{DM}=$ dry matter). Extra non-trial lambs were added when necessary to maintain allowance at $2.0 \mathrm{~kg} / \mathrm{ha}$. Lambs were rotationally grazed; plots were subdivided to give up to 14 days grazing/plot. Excess residual herbage was removed by grazing with a large mob of drystock and/or 
topping to approximately $50 \mathrm{~mm}$. Regrowth periods were between 28 and 35 days. Grazing started in midJanuary in year one, mid-November in year two and early December in year three; grazing continued for 83 days in year one, and 120 in years two and three.

Herbage DM yield (kg DM/ha) was assessed preand post-grazing by the trial lambs using $8 \times 0.25 \mathrm{~m}^{2}$ quadrats per replicate cut to ground level. In year one, DM intake was calculated using chromic oxide (Parker et al. 1991). Herbage was analysed during the first year of the trial for digestibility and protein content.

Animals were weighed (non-fasted) every 10 days (to check that animals were gaining weight) and at the end of the trial fasted (24-hour) liveweights and carcass weights were obtained. Lamb liveweight gains were calculated from fasted weights.

The weight of greasy wool grown was determined by shearing all lambs at the start of the trial and 10 days before slaughter.

Results were analysed using standard errors and regression analysis (QuattroPro).

\section{Results and discussion}

Analysis of herbage harvested before grazing on 24/2/1993 indicated that chicory and white clover had the highest digestibility and white clover, lotus and chicory had the highest protein content (Table 1). Plantain stem had a very low digestibility and protein content, and in late summer and autumn stem made up $60 \%$ of the plantain on offer. Intake measured in year one was greatest on chicory and white clover and least on ryegrass and plantain plots (Table 1).

Lambs grew significantly faster on white clover and chicory plots than on ryegrass and plantain plots in each of the three, years as indicated by liveweight gain (Table 2), fasted liveweights at slaughter (Table 3) and carcass weights (Table 4).

Wool production (Table 5) was higher on lotus and white clover than on chicory, which in turn gave higher greasy fleece weight than plantain and ryegrass. These results support the conclusion (Wang et al. 1994) that condensed tannins in lotus increase wool growth. The fact that plantain did not increase wool growth throws some doubt on whether it does actually contain tannins, and supports data presented by Robertson et al. (1995). The "tannin" extraction could be confused by the presence of aucubin (Stewart 1996). Hot carcass weight was positively, linearly and significantly related to wool weight in year $2\left(\mathrm{R}^{2}=0.70\right)$ and in year $3\left(\mathrm{R}^{2}=0.57\right)$.

Table 1 Herbage quality (digestibility \% and protein \%;24/2/1993) and intake over a 5 -day period $(\mathrm{kg} \mathrm{DM} / \mathrm{head} /$ day) in year one.

\begin{tabular}{lcccccc}
\hline $\begin{array}{l}\text { Herbage } \\
\text { quality }\end{array}$ & Chicory & $\begin{array}{c}\text { Plantain } \\
\text { leaf }\end{array}$ & $\begin{array}{c}\text { Plantain } \\
\text { stem }\end{array}$ & $\begin{array}{c}\text { White } \\
\text { clover }\end{array}$ & Lotus & Ryegrass \\
\hline Digestibility \% & 84.8 & 80.4 & 58.7 & 83.0 & 79.8 & 80.2 \\
Protein \% & 24.3 & 20.2 & 13.8 & 28.0 & 25.7 & 20.1 \\
Hemicellulose \% & 2.34 & 7.48 & 14.55 & 5.21 & 7.01 & 24.5 \\
Cellulose \% & 11.28 & 11.93 & 22.63 & 15.26 & 12.07 & 18.34 \\
Lignin & 3.34 & 2.85 & 4.98 & 2.7 & 3.46 & 1.81 \\
Intake & 1.94 & 1.44 & & 1.77 & n/a & 1.03 \\
(kg DM/head/day) & & & & & & \\
\hline
\end{tabular}

Table 2 Effect of pasture species on lamb liveweight gain (g/ head/day).

\begin{tabular}{lccccc}
\hline Year & Chicory & Plantain & $\begin{array}{c}\text { White } \\
\text { clover }\end{array}$ & Lotus & Ryegrass \\
\hline One & $182 \pm 6.4^{1}$ & $141 \pm 5.4$ & $219 \pm 5.1$ & $\mathrm{n} / \mathrm{a}^{2}$ & $128 \pm 3.9$ \\
Two & $181 \pm 6.2$ & $84 \pm 4.6$ & $225 \pm 4.4$ & $175 \pm 4.2$ & $98 \pm 4.5$ \\
Three & $214 \pm 6.8)$ & $102 \pm 4.4$ & $233 \pm 6.6$ & $239 \pm 9.6$ & $136 \pm 4.9$ \\
\hline
\end{tabular}

1 standard errror

2 not available

Table 3 Effect of pasture species on fasted liveweights $(\mathrm{kg})$ at slaughter.

\begin{tabular}{lccccc}
\hline Year & Chicory & Plantain & $\begin{array}{c}\text { White } \\
\text { clover }\end{array}$ & Lotus & Ryegrass \\
\hline One & $38.2 \pm 0.53^{1}$ & $35.1 \pm 0.62$ & $41.6 \pm 0.7$ & $\mathrm{n}^{2} \mathrm{a}^{2}$ & $34.5 \pm 0.44$ \\
Two & $43.7 \pm 0.9$ & $32.1 \pm 0.79$ & $49.0 \pm 0.67$ & $43.0 \pm 0.64$ & $33.8 \pm 0.55$ \\
Three & $47.7 \pm 0.77$ & $33.9 \pm 0.75$ & $49.8 \pm 0.90$ & $50.5 \pm 1.26$ & $38.4 \pm 0.75$ \\
\hline 1 & & & & \\
2 standard errror & & & & \\
\hline
\end{tabular}

Table 4 Effect of pasture species on carcass weights (kg).

\begin{tabular}{lccccc}
\hline Year & Chicory & Plantain & $\begin{array}{c}\text { White } \\
\text { clover }\end{array}$ & Lotus & Ryegrass \\
\hline One & $18.3 \pm 0.36^{1}$ & $16.8 \pm 0.38$ & $20.1 \pm 0.38$ & $\mathrm{n}^{2} \mathrm{a}^{2}$ & $15.6 \pm 0.35$ \\
Two & $20.8 \pm 0.58$ & $14.1 \pm 0.38$ & $23.4 \pm 0.33$ & $19.3 \pm 0.31$ & $14.6 \pm 0.26$ \\
Three & $26.0 \pm 0.41$ & $17.1 \pm 0.57$ & $25.1 \pm 0.85$ & $25.9 \pm 0.57$ & $18.4 \pm 0.47$ \\
\hline 1 & standard errror & & & & \\
2 & & & & \\
\hline
\end{tabular}

Table 5 Effect of pasture species on greasy wool production $(\mathrm{kg})$.

\begin{tabular}{lccccc}
\hline Year & Chicory & Plantain & $\begin{array}{c}\text { White } \\
\text { clover }\end{array}$ & Lotus & Ryegrass \\
\hline One & $1.62 \pm 0.03^{1}$ & $1.48 \pm 0.02$ & $1.79 \pm 0.04$ & $\mathrm{n} / \mathrm{a}^{2}$ & $1.42 \pm 0.04$ \\
Two & $2.15 \pm 0.06$ & $1.61 \pm 0.05$ & $2.48 \pm 0.07$ & $2.26 \pm 0.05$ & $1.69 \pm 0.04$ \\
Three & $2.54 \pm 0.07$ & $1.79 \pm 0.09$ & $2.69 \pm 0.07$ & $2.86 \pm 0.11$ & $1.69 \pm 0.08$ \\
\hline 1 & & & & \\
2 & standard error & & & & \\
\hline
\end{tabular}


Based on a limited data set, protein (\%) (Table 1) accounted for $83-92 \%$ of the variation in growth rate, fasted liveweight, hot carcass weight and wool weight (Table 6). In contrast, intake accounted for $57-69 \%$ of the variation in performance indicators. Intake was negatively and significantly correlated with hemicellulose and cellulose content $\left(\mathrm{R}^{2}=97.2\right.$ and $80.9 \%$, respectively); protein accounted for only $42 \%$ of the variability in intake and digestibility only $18 \%$. Clearly, to achieve high performance, sheep require pasture of high protein but low hemicellulose and cellulose concentrations. Results support the view that protein supply limits the performance of animals grazing improved pastures.

Table 6 Coefficients of determination $\left(\mathrm{R}^{2}\right)$ between protein concentration of pasture or intake of pasture and production parameters averaged over three years.

\begin{tabular}{lcc}
\hline & Protein (\%) & Intake (kg DM/head/day) \\
\hline $\begin{array}{l}\text { Liveweight gain } \\
\quad(\mathrm{g} / \text { head/day) }\end{array}$ & $91.3 \pm 5.5$ & $60.7 \pm 5.1$ \\
Fasted liveweight $(\mathrm{kg})$ & $92.2 \pm 3.9$ & $57.4 \pm 2.7$ \\
Carcass weight $(\mathrm{kg})$ & $82.9 \pm 7.6$ & $69.0 \pm 3.3$ \\
Wool weight $(\mathrm{kg})$ & $86.9 \pm 8.0$ & $66.1 \pm 12.6$ \\
\hline standard error & & \\
\hline
\end{tabular}

\section{Conclusions}

Results from this trial confirm that quality of feed is a major factor in animal performance. High protein pastures gave lamb growth rates over $200 \mathrm{~g}$ /day at a modest feed allowance of $2 \mathrm{~kg} \mathrm{DM} / \mathrm{head}$. There was no evidence to suggest that the tannins (Launert 1984; Dorfler \& Roselt 1989) and antibiotic properties (Grieve 1931) of plantain had any beneficial effect on animal production. Furthermore, in comparison with white clover and chicory, plantain was not "highly palatable to stock", thus conflicting with Milton (1933) and Ivins (1952).

The results confirm that for improved animal performance, the pasture breeder should be aiming for a plant with high protein and low hemicellulose and cellulose contents.

\section{ACKNOWLEDGEMENTS}

The authors would like to thank the Meat Research Development Council and the Foundation for Research, Science and Technology for funding, and Mrs J. Deaker, Mr T. Knight and Miss K. Sanders for assistance.

\section{REFERENCES}

Clark, D.A.; Anderson, C.B.; Hongwen, G. 1990. Liveweight gain and intake of Friesian bulls grazing 'Grasslands Puna' chicory (Cichorium intybus L.) or pasture. New Zealand journal of agricultural research 33: 219-224.

Dorfler, H.; Roselt, G. 1989. The dictionary of healing plants. London, New York and Sydney: Blandford Press. 328pp.

Foster, L. 1988. Herbs in pastures. Development and research in Britain. Biological agriculture and horticulture 5: 97-133.

Fraser, T.J.; Cosgrove, G.P.; Thomas, W.J.; Stevens, D.R.; Hickey, M.J. 1988. Performance of Grasslands Puna chicory. Proceedings of the New Zealand Grassland Association 49: 193-196.

Grieve, M. 1931. A modern herbal. Great Britain: Jonathan Cape Ltd. 912pp.

Heeger, E.F. 1949. Medicinal herbs for seed mixtures for meadows and pastures. Deutsche Landie 3: 116117.

Hughes, T.P.; Poppi, D.P.; Sykes, A.R. 1980. Some implications of sward chemical and physical characteristics for the nutrition of grazing ruminants. Proceedings of the New Zealand Society of Animal Production 40: 68-84.

Ivins, J.D. 1952. The relative palatability of herbage plants. Journal of the British Grassland Society 7: 43-54.

Komolong, M.; Nicol, A.M.; Poppi, D.P.; Fraser, T.J.; Kirsopp, S. 1992. Nutrient supply for lamb growth from Grasslands Puna chicory (Cichorium intybus) and Wana cocksfoot (Dactylis glomerata). Proceedings of the New Zealand Society of Animal Production 52: 85-87.

Launert, E. 1984. The country life guide to edible and medicinal plants of Britain and Northern Europe. England: Country Life Books. 288pp.

Milton, W.E.G. 1933. The palatability of the selfestablishing species contributing to the different types of grassland. Empire journal of experimental agriculture 1: 347-360.

Parker, W.J.; McCutcheon, S.N.; Wickham, G.A. 1991. Effect of administration and ruminal presence of chromic oxide controlled release capsules on herbage intake of sheep. New Zealand journal of agricultural research 34: 193-200.

Robertson, H.A.; Niezen, J.H.; Waghorn, G.C.; Charleston, W.A.G.; Jinlong, M. 1995. The effects of six herbages on liveweight gain, wool growth and faecal egg count of parasitised ewe lambs. Proceedings of the New Zealand Society of Animal Production 55: 199-201. 
Rumball, W. 1986. 'Grasslands Puna' chicory (Cichorium intybus). New Zealand journal of experimental agriculture 14: 105-107.

Stewart, A. 1996. Plantain (Plantago lanceolata) - a potential pasture species. Proceedings of the New Zealand Grassland Association: (this proceedings).

Thomas, B.; Thompson, A.; Oyenuga, V.A.; Armstrong, R.H. 1952. The ash constituents of some herbage plants at different stages of maturity. Empire journal of experimental agriculture 20: 10-22.
Wang, Y.; Waghorn, G.C.; Douglas, G.B.; Barry, T.N.; Wilson, G.F. 1994. The effects of condensed tannin in Lotus corniculatus upon nutrient metabolism and upon body and wool growth in grazing sheep. Proceedings of the New Zealand Society of Animal Production 54: 219-222.

Wilman, D.; Riley, J.A. 1993. Potential nutritive value of a wide range of grassland species. Journal of agricultural science, Cambridge 120: 43-49. 